\begin{tabular}{|c|l|}
\hline Title & Biotechnological potential of marine natural products \\
\hline Author(s) & Fusetani, Nobuhiro \\
\hline Citation & $\begin{array}{l}\text { Pure and A pplied Chemistry, 82(1), 17-26 } \\
\text { https://doi.org/10.1351/PAC-CON-09-01-11 }\end{array}$ \\
\hline Issue Date & 2010-01 \\
\hline Doc URL & http://hdl.handle.net/2115/42722 \\
\hline Rights & ○ 2010 IUPAC \\
\hline Type & article \\
\hline File Information & PAC82-1_17-26.pdf \\
\hline
\end{tabular}

Instructions for use 
Pure Appl. Chem., Vol. 82, No. 1, pp. 17-26, 2010.

doi:10.1351/PAC-CON-09-01-11

(C) 2010 IUPAC, Publication date (Web): 3 January 2010

\title{
Biotechnological potential of marine natural products*
}

\author{
Nobuhiro Fusetani ${ }^{\ddagger}$ \\ Faculty of Fisheries Sciences, Hokkaido University, Hakodate 041-8611, Japan
}

\begin{abstract}
The number of marine natural products (MNPs) that have been applied to biotechnological industry is very limited, although nearly 20000 new compounds were discovered from marine organisms since the birth of MNPs in the early 1970s. However, it is apparent that they have a significant potential as pharmaceuticals, cosmetics, nutraceuticals, research tools, and others. This article focuses on selective antitumor metabolites isolated from marine sponges and tunicates and their modes of action, as well as promising candidates for nontoxic antifoulants discovered from marine organisms.
\end{abstract}

Keywords: antifoulants; antitumor compounds; biotechnology; marine natural products; pharmaceuticals; research tools.

\section{INTRODUCTION}

Tyrian purple (1), a brilliant purple dye documented in texts dating from about the $16^{\text {th }}$ century B.C., was produced from the hypobrachial glands of marine gastropod mollusks of the superfamily Muricacea [1]. This was man's first large-scale marine biotechnological industry originating in Tyre, a Phoenician city. However, the application of marine natural products (MNPs) to industry started quite recently, because of man's limited access to marine resources during virtually all of recorded history. MNPs are potential sources of pharmaceuticals, cosmetics, nutraceuticals, agrochemicals, and others. Their application to drugs has been explored since the early 1970s, but only a small number of MNPs have been applied to pharmaceuticals [2]. Recently, the increasing numbers of MNPs have been developed for nutraceuticals [3] and cosmetics [4]. It should be noted that many MNPs, especially toxins (e.g., tetrodotoxin) have been used as research tools (reagents) and contributed enormously to the progress of life science. Surprisingly, only nereistoxin isolated from a polychaete was applied to an agrochemical [5]. This article focuses on selective antitumor compounds that we isolated from Japanese marine invertebrates and their modes of action, as well as MNPs applicable to nontoxic antifoulants.<smiles>O=C1/C(=C2\Nc3cc(Br)ccc3C2=O)Nc2cc(Br)ccc21</smiles>

\footnotetext{
*Paper based on a presentation at the $13^{\text {th }}$ International Biotechnology Symposium (IBS 2008): "Biotechnology for the Sustainability of Human Society", 12-17 October 2008, Dalian, China. Other presentations are published in this issue, pp. 1-347. *Tel./Fax: +81-138-40-8884; E-mail: anobu@ fish.hokudai.ac.jp
} 


\section{ANTITUMOR COMPOUNDS}

Bergmann's discovery of novel nucleosides, namely, spongouridine and spongothymidine, from a Caribbean sponge in the early 1950s led to the development of an anticancer drug, Ara-C (cytarabine) (2) [2]. Being stimulated by this event, significant efforts toward the development of anticancer drugs from marine organisms have been made since the early 1970s, which led to the isolation of a large array of compounds having potent cytotoxicity as well as novel structures [6]. More than 30 MNPs and their derivatives have entered clinical trials as anticancer drugs. Finally, yondelis/ectenascidin 734 (3), discovered from a Caribbean tunicate, has been approved for treatment of soft tissue sarcoma in the European Union in 2007; however, clinical trials of several MNPs have been discontinued [7].<smiles>NC1=NC(=O)C2C3OC(C(O)C3CO)C2O1</smiles>

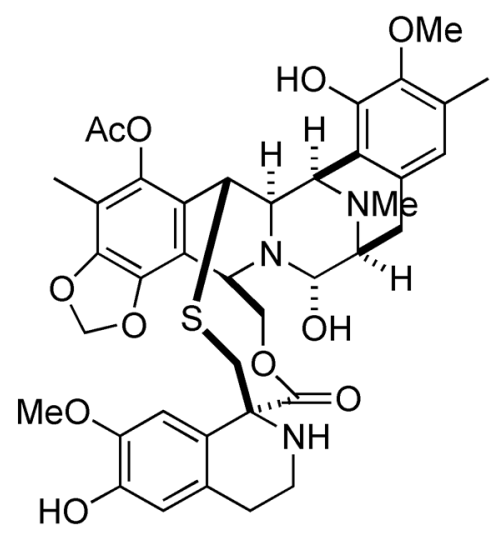

3

For nearly 30 years, we have been involved in the discovery of antitumor leads from Japanese marine invertebrates, especially sponges and tunicates, by employing cell-based and enzyme inhibition assays, which resulted in the isolation of a number of structurally novel and highly potent cytotoxic metabolites [8]. Although none of them have entered clinical trials, a handful of compounds whose modes of action have been elucidated are used as research tools (reagents).

Kabiramide C (4), isolated from egg masses of a nudibranch of the genus Hexabranchus (Mollusca; Opisthobranchia), is an unprecedented trisoxazole-containing macrolide with polyketide 
side chain [9]. Later, mycalolide B (5), a macrolide with essentially the same framework, was isolated from sponges of the genus Mycale [10]. These compounds showed strong cytotoxicity along with potent antifungal activity, but their in vivo antitumor activity was disappointing due to high toxicity. The mode of action study revealed that these maclorides bind to G-actin in a molar ratio of 1:1, thereby inhibiting actin polymerization as well as sequestering liberated actin monomers, resulting in depolymerization of actin filaments [11]. Recently, the crystal structure of the complex between kabiramide $\mathrm{C}$ and G-actin was solved [12]; the polyketide side chain, particularly the $N$-methyl vinylformamide group, plays a crucial role in binding to the actin. Interestingly, kabiramide $\mathrm{C}$ mimics the action of gelsolin, an actin-binding protein. An unusual macrodiolide, bistheonellide A (6) derived from a marine sponge Theonella sp., showed biological activities similar to those of the trisoxazole-containig macrolides. In fact, it binds to G-actin in a molar ratio of 1:2 [13] A similar mode of action was observed for several MNPs [12].

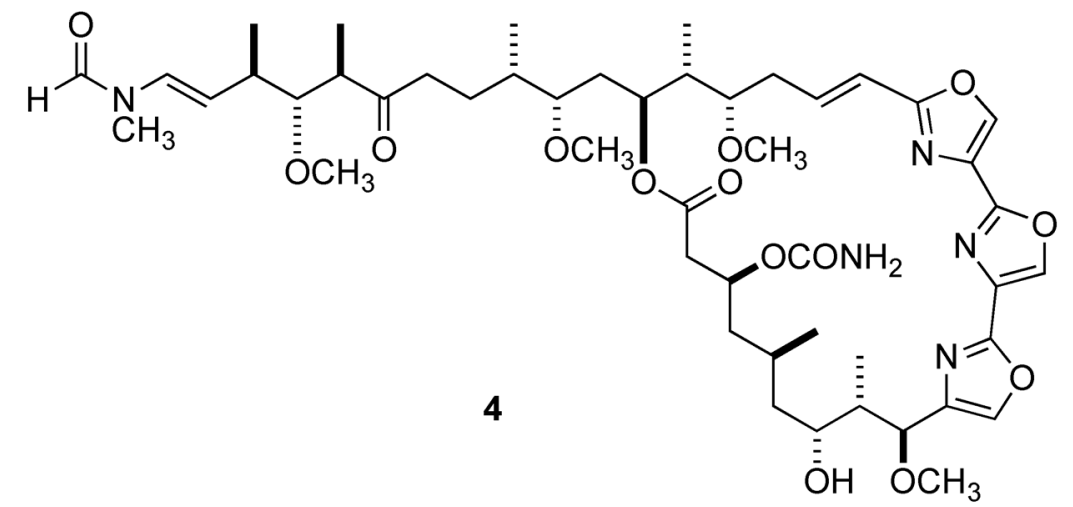

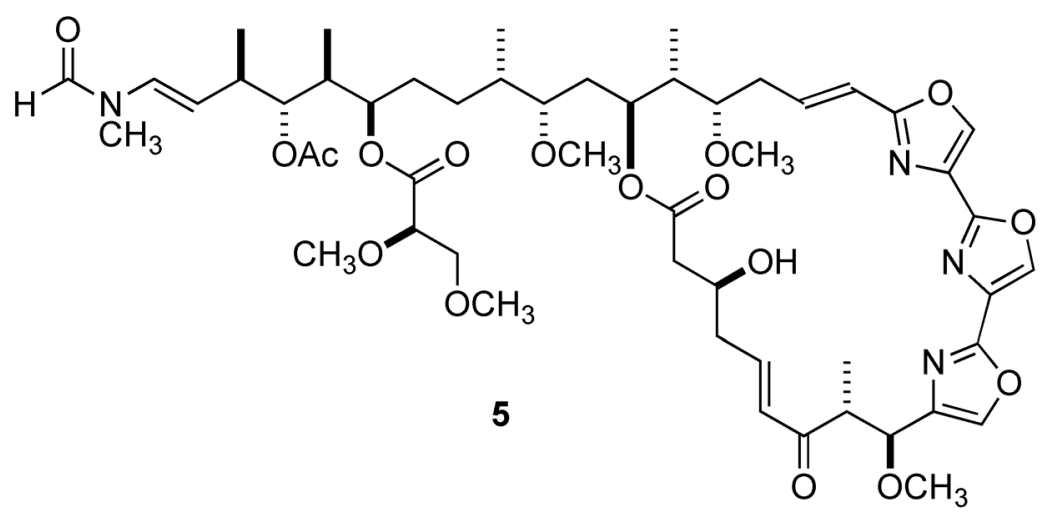




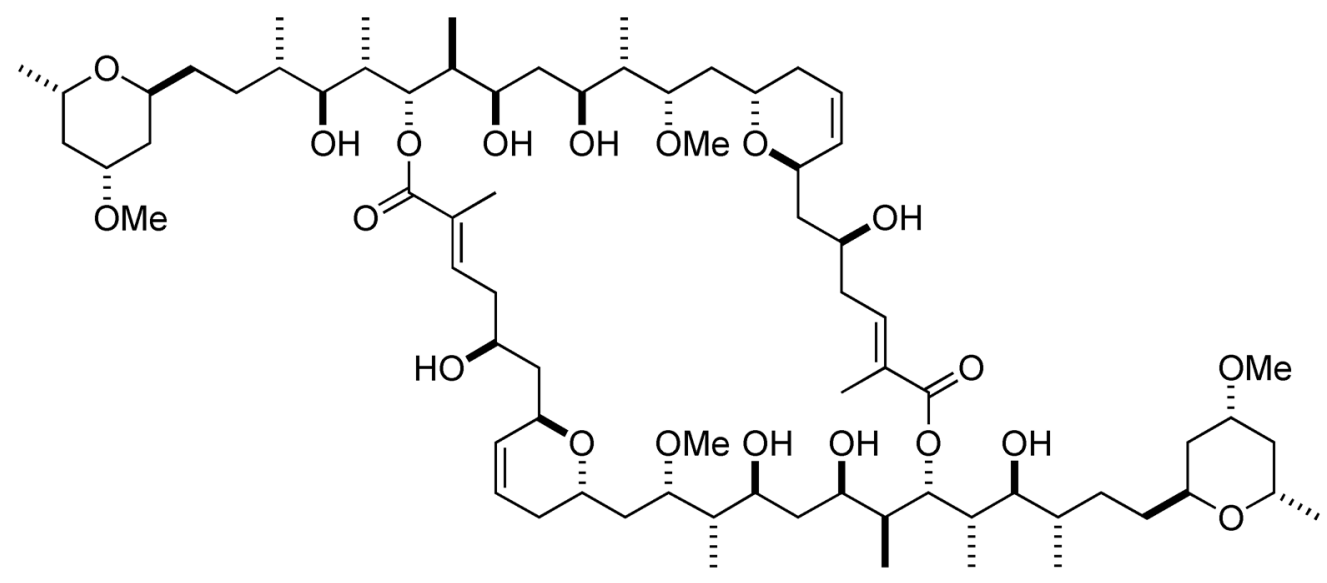

6

Calyculin A (7) is an extraordinary metabolite of polyketide/non-ribosomal peptide synthase isolated from the Japanese marine sponge Discodermia calyx. It is not only highly cytotoxic $\left(\mathrm{IC}_{50}\right.$ $0.74 \mathrm{ng} / \mathrm{ml}$ against L1210 leukemia cells) but also strongly antifungal. Calyculin A showed potent in vivo antitumor activity (T/C $246 \%$ at $15 \mu \mathrm{g} / \mathrm{kg}$ against Ehrich ascites tumor cells; mice); however, unfortunately, it is highly toxic to mice [14]. Later, calyculin A was demonstrated to be a potent cancer promoter which was then found to be due to selective inhibition of protein phosphatases (PPs) 1 and 2A [15]. Reversible serine/threonine phosphorylation regulates numerous biological functions, including cellular signal transduction. Therefore, selective inhibitors of protein kinases or PPs are important tools for life science research. In fact, natural protein PP inhibitors have contributed greatly to our understanding of biological processes [16]. Structure-activity relationship study using natural and chemically transformed calyculins disclosed that 17-phosphate, 11- and 13-hydroxyl, and hydrophobic tetraene moieties are all necessary for binding to PP1 [17]. This finding was also supported by the crystal structure of PP1/calyculin A complex where calyculin A binds to the catalytic region of the enzyme [18].

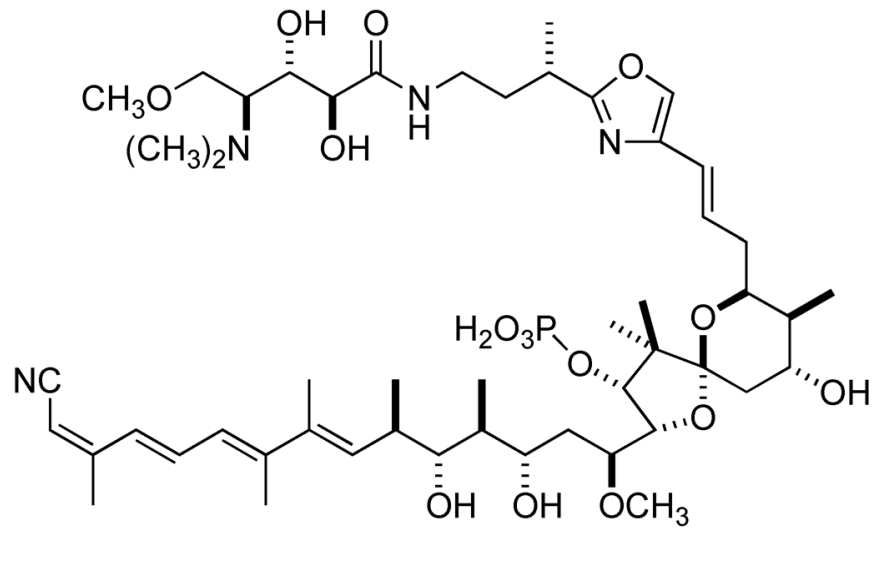

7

13-Deoxytedanolide (13-DT) (8), an 18-membered macrolide isolated from marine sponges of the genus Mycale, shows not only potent cytotoxicity $\left(\mathrm{IC}_{50}<0.14 \mathrm{ng} / \mathrm{ml}\right.$ against $\mathrm{P} 388$ leukemia cells) 
but also promising antitumor activity [19]. However, a severe side effect prevented its application to anticancer drugs. Again, structure-activity relationship study indicated the southern hemisphere of the molecule is the pharmacophore [20]. Since the $11 S$-dihydro derivative retains cytotoxicity, the tritiumlabeled derivative was prepared and subjected to binding assay using the budding yeast lysates, resulting in that 13-DT binds to ribosome. Further experiments revealed that 13-DT strongly binds to the 60S large subunit of ribosome. In fact, 13-DT inhibits polypeptide elongation. Actually, 13-DT is the first macrolide that binds to eukaryotic ribosome [21].

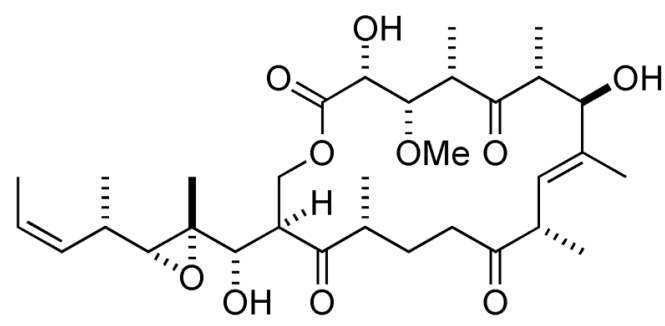

8

The marine sponge Thenoella swinhoei with yellow interior is quite productive, containing a variety of metabolites with unusual structures and potent bioactivities, among which theopederin A (9) showed promising antitumor activity $\left(\mathrm{IC}_{50} 0.05 \mathrm{ng} / \mathrm{ml}\right.$ against $\mathrm{P} 388$ leukemia cells). Unfortunately, its very low yield prevented further in vivo testing [22]. Interestingly, it has the same framework of pederin (10), the venom of blister beetles of the genus Paederus. Competitive binding assay with the radiolabeled 13-DT derivative showed that these compounds share the binding site on 60S large ribosomal subunit with 13-DT [21].<smiles>C=C1C[C@@](O)([C@H](O)C(=O)N[C@H]2OCOC3C2O[C@H](C[C@@H]2CCC[C@H](O)O2)C(C)(C)[C@@H]3OC)O[C@H](C)C1C</smiles>

9<smiles>C=C1C[C@](O)([C@H](O)C(=O)N[C@H](OC)C2C[C@H](O)C(C)(C)[C@@H](C[C@@H](COC)OC)O2)O[C@H](C)C1C</smiles>

10

Tunicates have been also proved to be sources of highly cytotoxic metabolites as ecteinacidin 743 and aplidine [2]. Ritterazines A-Z [ritterazine B (11); $\mathrm{IC}_{50} 0.15 \mathrm{ng} / \mathrm{ml}$ against P388 cells] are highly cytotoxic unusual dimeric steroids isolated from the Japanese tunicate Ritterella tokioka [23]. Closely related compounds named cephalostatins [cephalostatin 1 (12)] were reported from the phylogenetically remote, hemicordate Cephalodiscus glichristi [24]. These compounds induce apoptosis strongly by the unusual mechanism [25]. Shishijimicins A-C [shishijimicin A (13)], unprecedented $\beta$-carbolinecontaining endiynes isolated from the tunicate Didemnum proliferum collected in southern Japan, showed remarkable cytotoxicity $\left(\mathrm{IC}_{50} \mathrm{~s}^{\prime} 1.8-6.3 \mathrm{pM}\right.$ against HeLa cells) [26]. Presumably, they cleave DNA chain as other endiynes do [27]. 


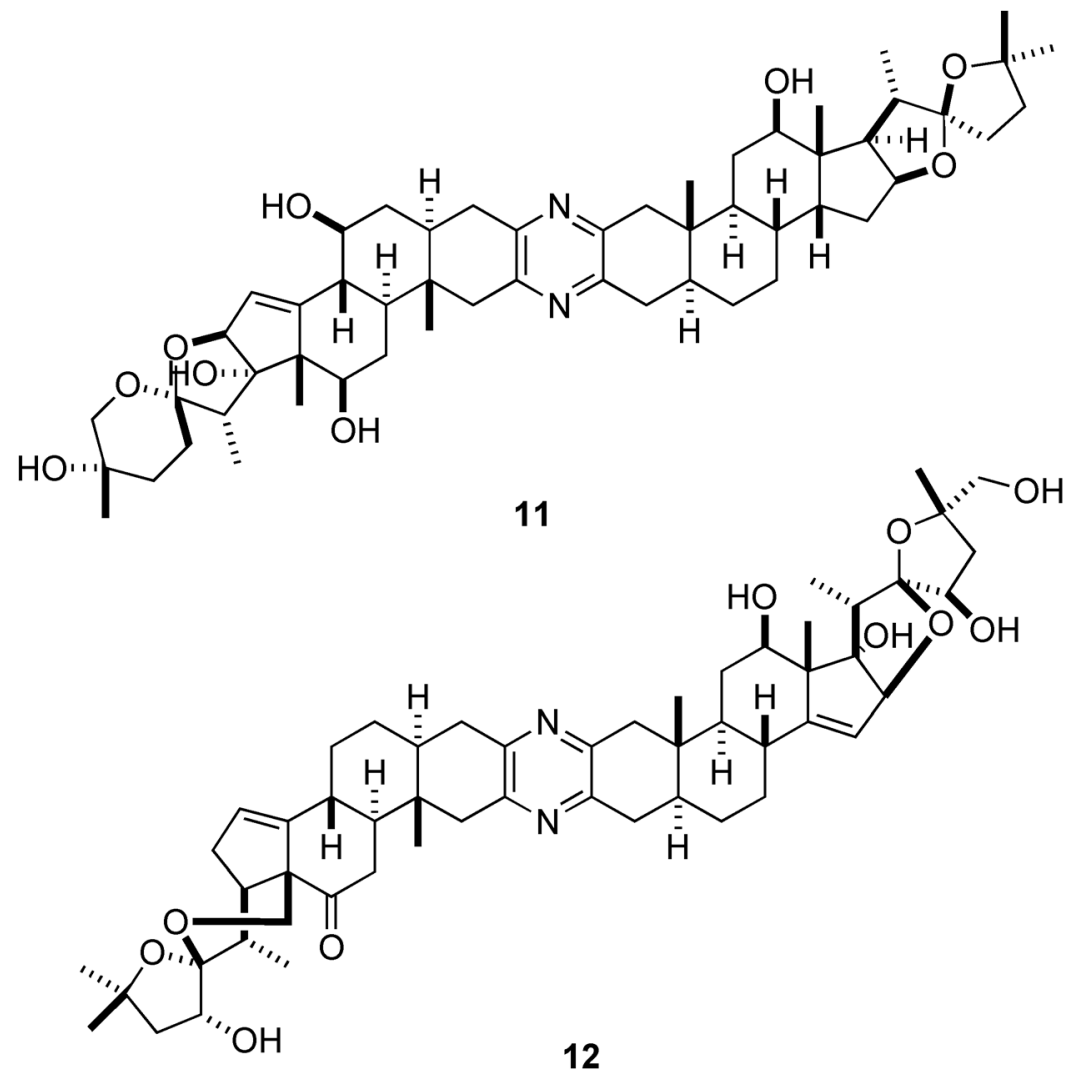

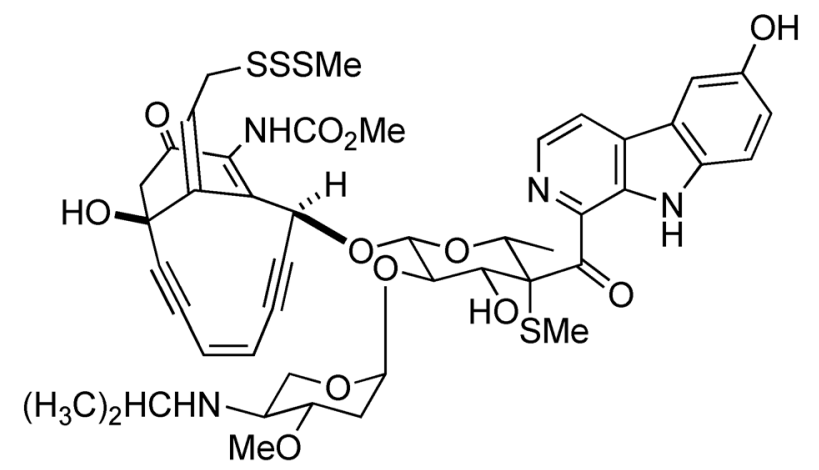

\section{ENZYME INHIBITORS}

Matrix metalloproteinases (MMPs), a family of Zn-containing endopeptidases, have been a target for cancer chemotherapy [28]. Among a number of inhibitors we isolated from marine sponges, the most interesting inhibitor is ageladine A (14), a fluorescent oroidin derivative, discovered from the marine sponge Agelas nakamurai; it not only inhibits various MMPs at low concentration but also angiogenesis [29]. 
<smiles>Nc1nc2c(-c3cc(Br)c(Br)[nH]3)nccc2[nH]1</smiles>

14

Telomerase is a reverse transcriptase that adds telomere sequences (TTAGGG) onto the 3 "-end of chromosomes and expressed in $90 \%$ human tumor cells, but not in normal cells [30]. Therefore, its inhibitors are potential anticancer drugs; indeed, some synthetic inhibitors have been successful in cancer chemotherapy. Axinelloside A (15), isolated from the marine sponge Axinella imfundebula, is an unprecedented highly sulfated lipopolysaccharide, comprised of 12 sugars, 19 sulfates, and 4 fatty acids [31]. It inhibits telomerase at $\mathrm{IC}_{50} 2 \mu \mathrm{g} / \mathrm{ml}$; perhaps sulfate groups are important for the activity.

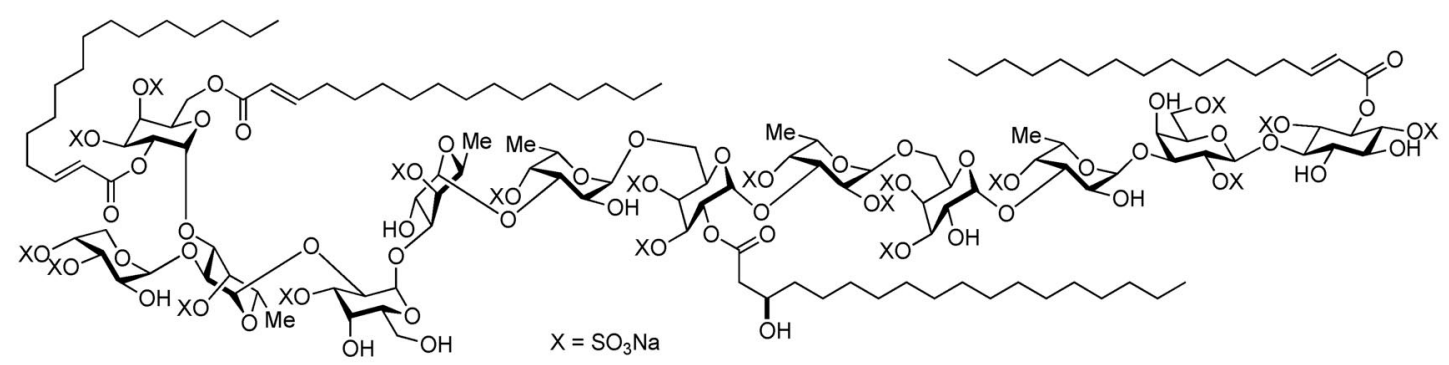

Histone deacetylases (HDACs) remove acetyl groups from acetylated lysine residues of histone, and its inhibitors show antitumor activity and some inhibitors have entered clinical trials [32]. Azumamide A-E [azumamide A (16)] are cyclic tetrapeptides containing a new amino acid isolated from the marine sponge Mycale izuensis collected in southern Japan [33]. They inhibit a human leukemia HDAC at low concentrations. Importantly, they inhibit vascular formation in ES cells.<smiles>CC(C)C(C)NC(=O)C1NC(=O)[C@H](C)C(C/C=C/CCC(N)=O)NC(=O)C(Cc2ccccc2)NC1=O</smiles> 


\section{NONTOXIC ANTIFOULANTS}

Macrofouling on man-made submersible structures, namely, ships' hulls, cooling systems for power plants, and aquaculture facilities, cause enormous economic losses. Combats against fouling organisms started when humans built boats. However, protection of ships' hulls from fouling goes back more than 2000 years. Various toxic materials have been used for control of fouling organisms, among which organotin compounds, especially tributyltin (TBT) and tributyltin oxide (TBTO), are remarkably effective. However, the adverse effects of organotin compounds on marine organisms became evident in Europe and other regions by the mid-1980s, and the International Maritime Organization (IMO) decided to ban TBT/TBTO coating on ships completely from 2008. Cupuric oxide-based paints and biocide-based "booster" paints have been introduced as alternative paints; however, these paints also showed environmental problems in recent years [34]. Therefore, development of nontoxic or environmentally friendly antifoulants has been urgently required.

An approach to nontoxic antifouling strategy is to apply chemical defense of sessile marine organisms; they maintain their body surfaces clean. In fact, such important antifouling compounds as furanones, pukalide, and renillafoulin were isolated from sessile organisms [35]. Furanones (e.g., 17), isolated from the Australian red alga Delisea pulchra, are potent bacterial quorum sensing inhibitors, but the mechanism of their antifouling activity against macrofouling is unknown. Furanone (18), a synthetic analog, is under development for antifoulants and other products [36]. 2,5,6-Tribromo-1-methylgramine (19) found from the Japanese bryozoan Zoobotryon pellucidum showed remarkable antifouling activity, and more than 150 analogs and derivatives were evaluated for antifouling activity; 5,6-dichloro-1methygramine was selected as a candidate for nontoxic antifoulant. Since the panel tests showed promising results, a large-scale, 5-year field test has been under way in Japan [37].

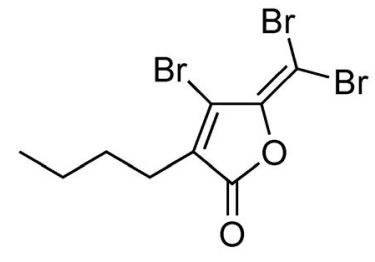

17<smiles>O=C1C=C(Br)/C(=C/Br)O1</smiles>

18<smiles>CN(C)Cc1c(Br)[nH]c2cc(Br)c(Br)cc12</smiles>

19

The Fusetani Biofouling Project explored nontoxic antifouling compounds from sessile marine invertebrates using "cyprid assay", which resulted in isolation of more than 65 antifouling compounds, including 35 new compounds. The most promising antifouling compounds we discovered are sesquiand diterpenoid isocyanides isolated from the marine sponge Acanthella cavernosa and nudibranchs of the family Phyllidiidae [38]. 4-Isocyanotheonellin (20) was selected as a model compound for development of nontoxic antifoulants, and more than 70 isocyanotheonellin analogs and much simpler isocyanides were synthesized and evaluated by the cyprid assay. Finally, a simple alkyl isocyanide (21) was selected and evaluated its antifouling activity in the field. A preliminary field test showed promising results [39].<smiles>CC(=CC=CC(C)C)C1CCC(C)(N)CC1</smiles>

20

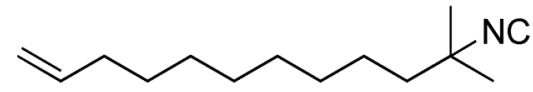

21 


\section{CONCLUSION}

Marine invertebrates, especially sponges and tunicates, are rich sources of bioactive small molecules applicable to biotechnological industry. However, the most serious obstacle for their industrial applications is the supply problem (the problem of supplying sufficient material for drug development and others); most of the promising MNPs are contained at very small concentrations, usually $10^{-4}-10^{-6} \%$ of wet tissue, and have complex structures [40]. Thus, detailed studies on structure-activity relationships, modes of action, and others required for industrial applications cannot be carried out. How do we solve this problem? Chemical synthesis is not mature yet to synthesize kilogram-scale of complex molecules; perhaps one of the solutions is "diverted total synthesis" [41]. Aquaculture of sponges, bryozoans, and tunicates has been attempted to produce anticancer drugs, which is not realistic for large-scale production of drugs [42]. Perhaps cloning and heterologous expression of biosynthetic enzymes of drug candidates is most promising [43], since many drug candidates seem to be produced by symbiotic microorganisms that are uncultured [44].

\section{REFERENCES}

1. P. E. McGovern, R. H. Michel. Acc. Chem. Res. 23, 152 (1990).

2. D. J. Newman, G. M. Cragg. J. Nat. Prod. 67, 1216 (2004).

3. V. Venugopal. Marine Products for Healthcare: Functional and Bioactive Nutraceutical Compounds from the Ocean, CRC Press, Boca Raton (2008).

4. W. Fenical. Cosmet. Toilet. 116, 33 (2001).

5. Y. Hashimoto. Marine Toxins and Other Bioactive Marine Metabolites, Japan Scientific Societies Press, Tokyo (1979).

6. J. W. Blunt, M. H. G. Munro. Dictionary of Marine Natural Products, Chapman \& Hall/CRC, Boca Raton (2007).

7. M. S. Butler. Nat. Prod. Rep. 25, 475 (2008).

8. N. Fusetani. J. Synth. Org. Chem., Jpn. 62, 1073 (2004).

9. S. Matsunaga, N. Fusetani, K. Hashimoto, K. Koseki, M. Noma. J. Am. Chem. Soc. 108, 847 (1986).

10. N. Fusetani, K. Yasumuro, S. Matsunaga, K. Hashimoto. Tetrahedron Lett. 30, 2809 (1989).

11. S. Saito, S. Watabe, H. Ozaki, N. Fusetani, H. Karaki. J. Biol. Chem. 269, 28710 (1994).

12. J. S. Allingham, V. A. Klenchin, I. Rayment. Cell. Mol. Life Sci. 63, 2119 (2006).

13. S. Saito, S. Watabe, H. Ozaki, M. Kobayashi, T. Suzuki, H. Kobayashi, N. Fusetani, H. Karaki. J. Biochem. 123, 571 (1998).

14. Y. Kato, N. Fusetani, S. Matsunaga, K. Hashimoto. Drugs Exptl. Clin. 14, 723 (1988).

15. H. Ishihara, B. L. Martin, D. L. Brautigan, H. Karaki, H. Ozaki, Y. Kato, N. Fusetani, S. Watabe, K. Hashimoto, D. Uemura, D. J. Hartshorne. Biochem. Biophys. Res. Commun. 159, 871 (1989).

16. V. Janssens, J. Goris. Biochem. J. 353, 417 (2001).

17. T. Wakimoto, S. Matsunaga, A. Takai, N. Fusetani. Chem. Biol. 9, 309 (2002).

18. A. Kita, S. Matsunaga, A. Takai, H. Kataiwa, T. Wakimoto, N. Fusetani, M. Isobe, K. Miki. Structure 10, 715 (2002).

19. N. Fusetani, T. Sugawara, S. Matsunaga, H. Hirota. J. Org. Chem. 56, 4971 (1991).

20. S. Nishimura, S. Matsunaga, S. Yoshida, Y. Nakao, H. Hirota, N. Fusetani. Bioorg. Med. Chem. 13, 455 (2005).

21. S. Nishimura, S. Matsunaga, M. Yoshida, H. Hirota, S. Yokoyama, N. Fusetani. Bioorg. Med. Chem. 13, 449 (2005).

22. N. Fusetani, T. Sugawara, S. Matsunaga. J. Org. Chem. 57, 3828 (1992).

23. S. Fukuzawa, S. Matsunaga, N. Fusetani. J. Org. Chem. 59, 6164 (1994). 
24. G. R. Pettit, M. Inoue, Y. Kamano, D. L. Herald, C. Arm, C. Dufresne, N. D. Christie, J. M. Schmidt, D. L. Doubek, T. S. Krupa. J. Am. Chem. Soc. 110, 2006 (1988).

25. A. Rudy, N. López-Antón, V. M. Dirsch, A. M. Vollinar. J. Nat. Prod. 71, 482 (2008).

26. N. Oku, S. Matsunaga, N. Fusetani. J. Am. Chem. Soc. 125, 2044 (2003).

27. K. C. Nicolaou, W.-M. Dai, S.-C. Tsay, V. A. Estevez, W. Wrasidlo. Science 256, 1172 (1992).

28. R. P. Verma, C. Hansch. Bioorg. Med. Chem. 15, 2223 (2007).

29. M. Fujita, Y. Nakao, S. Matsunaga, M. Seiki, Y. Itoh, J. Yamashita, R. W. M. van Soest, N. Fusetani. J. Am. Chem. Soc. 125, 15700 (2003).

30. J. W. Shay, W. E. Wright. Nat. Rev. Drug Discov. 5, 577 (2006).

31. K. Warabi, T. Hamada, Y. Nakao, S. Matsunaga, H. Hirota, R. W. M. van Soest, N. Fusetani. J. Am. Chem. Soc. 127, 13262 (2005).

32. R. W. Johnstone. Nat. Rev. Drug Discov. 1, 287 (2002).

33. Y. Nakao, S. Yoshida, S. Matsunaga, N. Shindoh, Y. Terada, K. Nagai, J. K. Yamashita, A. Ganesan, R. W. M. van Soest, N. Fusetani. Angew. Chem., Int. Ed. 45, 7553 (2006).

34. L. D. Chambers, K. R. Stokes, F. C. Walsh, R. J. K. Wood. Surf. Coat. Technol. 201, 3642 (2006).

35. P. J. Krug. In Antifouling Compounds, N. Fusetani, A. S. Clare (Eds.), pp. 1-53, Springer-Verlag, Berlin (2006).

36. R. de Nys, M. Givskov, N. Kumar, S. Kjelleberg, P. D. Steinberg. In Antifouling Compounds, N. Fusetani, A. S. Clare (Eds.), pp. 55-86, Springer-Verlag, Berlin (2006).

37. M. Kawamata, K. Kon-ya, W. Miki. In Antifouling Compounds, N. Fusetani, A. S. Clare (Eds.), pp. 125-139, Springer-Verlag, Berlin (2006).

38. N. Fusetani, H. Hirota, T. Okino, Y. Tomono, E. Yoshimura. J. Nat. Toxins 5, 249 (1996).

39. Y. Nogata, Y. Kitano. In Antifouling Compounds, N. Fusetani, A. S. Clare (Eds.), pp. 87-104, Springer-Verlag, Berlin (2006).

40. D. J. Faulkner. Antonie van Leeuwenhoek 77, 135 (2000).

41. I. Paterson, E. A. Anderson. Science 310, 451 (2005).

42. D. Sipkema, R. Osinga, W. Schatton, D. Mendola, J. Tramper, R. H. Wijffels. Biotechnol. Bioeng. 90, 201 (2005).

43. W. E. G. Müller, V. A. Grebenjuk, G. Le Pennec, H.-C. Schröder, F. Brümmer, U. Hentschel, I. M. Müller, H.-J. Breter. Mar. Biotechnol. 6, 105 (2004).

44. J. Piel. Curr. Med. Chem. 13, 39 (2006). 